\title{
Towards a Political Concept of Reversibility in International Relations: Bridging Political Philosophy and Policy Studies
}

\begin{abstract}
While contingency and negation are relatively well-established notions in the theoretical analysis of international relations, their practical implications remain under-conceptualised. In order to discuss the question of how to act under conditions of contingency and negation, this paper, in a first step, triangulates both with Aristotelian noesis. Such triangulation suggests that consequences of political action cannot be predicted and have always inadvertent consequences due to the contingent and historically and intellectually negated and refutable (even self-refutable) character of politics. It therefore appears as irresponsible to enact policies with interminable consequences. Rather, responsible political action - which is responsible precisely as, and only if, it accounts for contingency and negation - must hence act only in such a way that its consequences are reversible. In a second step, policy theory is critically reviewed in light of reversibility and its underlying philosophical principles, trying to bridge political philosophy and policy studies for a mutually enriched analysis of politics. Such a bridging exercise can not only bring enhanced normative reflection into policy studies, but in reverse hints at the crucial aspect of the non-linear unfolding of action consequences which is, next to questions for a future research agenda, discussed in the concluding section. These discussions are understood as a twofold, yet interlinked contribution: first, to develop a concept of reversibility as practical response to the philosophical notions of contingency and negation; and second, to bridge two different paradigms, encouraging the synergy of scholarly expertise for the management of contemporary international and global problems.
\end{abstract}

Keywords: contingency; critical theory; reflexive realism; reversibility; policy studies

Word count: 11281

\section{Prof Hartmut Behr}

International Politics, School of Geography, Politics, Sociology, Newcastle University 40-42 Great North Road

NE1 7RU

Tel.: +44 - (0)191 - 208 5705, email: Hartmut.behr@ncl.ac.uk

Hartmut Behr is Professor of International Politics at Newcastle University (UK). His research specializes in political theory, sociology of knowledge of IR, politics of difference, political violence, and critical European Studies. Most recent monograph publications include A History of International Political Theory (2010) and Politics of Difference: Epistemologies of Peace (2014) as well as book chapters and articles on the themes mentioned that appeared amongst others in the European Journal of International Relations, Geopolitics, Review of International Studies, International Political Economy, Zeitschrift für Internationale Beziehungen, Journal for International Political Theory, Ethics \& International Affairs, Journal of Intervention and Statebuilding. He holds a PhD from the University of Cologne and has taught and done research at Virginia Tech and the universities of Tokyo, Pittsburgh, Jena, and Ottawa. 


\title{
Towards a Political Concept of Reversibility in International Relations:
}

\section{Bridging Political Philosophy and Policy Studies}

\author{
Hartmut Behr
}

\begin{abstract}
While contingency and negation are relatively well-established notions in the theoretical analysis of international relations, their practical implications remain under-conceptualised. In order to discuss the question of how to act under conditions of contingency and negation, this paper, in a first step, triangulates both with Aristotelian noesis. Such triangulation suggests that consequences of political action cannot be predicted and have always inadvertent consequences due to the contingent and historically and intellectually negated and refutable (even self-refutable) character of politics. It therefore appears as irresponsible to enact policies with interminable consequences. Rather, responsible political action - which is responsible precisely as, and only if, it accounts for contingency and negation - must hence act only in such a way that its consequences are reversible. In a second step, policy theory is critically reviewed in light of reversibility and its underlying philosophical principles, trying to bridge political philosophy and policy studies for a mutually enriched analysis of politics. Such a bridging exercise can not only bring enhanced normative reflection into policy studies, but in reverse hints at the crucial aspect of the non-linear unfolding of action consequences which is, next to questions for a future research agenda, discussed in the concluding section. These discussions are understood as a twofold, yet interlinked contribution: first, to develop a concept of reversibility as practical response to the philosophical notions of contingency and negation; and second, to bridge two different paradigms, encouraging the synergy of scholarly expertise for the management of contemporary international and global problems.
\end{abstract}

Keywords: contingency; critical theory; reversibility; reflexive realism; policy studies 


\section{Introduction}

Political problems in the $21^{\text {st }}$ century demand radical imagination to cope with the most serious global challenges. The consequences of these problems existentially concern present and further generations as they fundamentally put the conditions of our societies and of the world at risk. For tackling respective problems, mono-paradigm and mono-disciplinary ways to analyse politics and to design policies are limited and in need of renegotiation. Radical imagination includes the questioning of the ways in which we are used to think and act in order to synergise expertise across and between disciplines and sub-disciplines to learn from each other. Researchers, political analysts, and policymakers must jointly develop new approaches to research and to political action. The synergy of cross-paradigm research across humanities and social sciences (and natural sciences, too) is therefore more conducive than epistemological and methodological silos. Concretely, this paper bridges philosophy in International Relations (IR) and policy process studies, speaking initially to two audiences, however, ultimately attempting to create a new audience through the interlocution of these two disciplines.

This bridging exercise between political philosophy in IR and policy studies seeks to create an avenue to develop normative thinking in policy studies and to move IR theory out of its theoretical corner into the terrain of political practice and policy-making. This interlocution addresses both the generic theory-practice problem in IR and provides an action-theoretical orientation in order to progress from reflection on the conditions of the possibility to a conceptual consideration of the possibility of responsible politics. This progress offers guidance dealing with contemporary political problems in a pluralist and contingent world in which we need policy norms without prescribing or determining the content of politics. As the bridging exercise has reciprocal learning effects, a concept of reversibility also needs to analyse the non-linearity, negation, and refutation of the temporal unfolding of policy consequences as alluded to by policy process studies. 
In the study of international politics, particularly in critical IR (inter alia Rengger/ThirkellWhite, 2011), ${ }^{1}$ contingency and negation have become acknowledged notions (inter alia Anievas, 2016; Katzenstein, 2018; Kessler, 2016; Kratochwil, 1991; Levine, 2012) due to the reception of a diverse spectrum of social and political theories. ${ }^{2}$ Yet although the theory-practice relation plays an important part in IR (inter alia Kratochwil, 2003; Lepgold, 1998; Zalewski, 1996; Smith, 2003; from a more orthodox IR angle, see Walt, 2005), the question of how contingency and dialectic negation inform political practice remains underdeveloped. Therefore, this paper explores the question of what kind of action and policies conclude from the non-linearity and perspectivity of contingent and always refuting and refuted politics. We need to go further than 'just' prudential, 'realist' admonitions to choose the lesser evil (Morgenthau, 1945; also Molloy 2009), important as this insight is.

In order to explore this question of the practical implications of the notions of contingency and dialectic negation, this paper triangulates both with the Aristotelian notion of noesis (which stresses the prime status of the human experience of political uncertainties, indeterminacies, and contingencies, emphasising the analytical awareness of the correspondence of political order with such experience). Seeing contingency, negation, and noesis as co-constitutive and irreducible conceptual elements of political ethics (Baumann, 1993), ${ }^{3}$ provides insights into what responsible political action mindful of the tensions of politics in a contingent and pluralist world would be like. Consequently, politics should and must not attempt to dissolve these tensions by claiming final answers and by acting upon them. ${ }^{4}$ Instead, we need to adopt a politics of reversibility, which will be developed in this paper as the scrutiny of policy consequences according to whether or not they harm the principles of contingency and negation. This implies that if policy decisions harm the principles of contingency and negation, then a politics of reversibility would stop the implementation of those policies. Policy-making therefore must be action-theoretically guided by the principle of non-irreversibility, ${ }^{5}$ i.e., by planning and implementing policies which do not violate or undermine contingency and negation as intrinsic conditions of politics. ${ }^{6}$ 
The paper proceeds in two main steps. The first section outlines the triangulation of contingency, negation, and noesis, examining the formulation of each concept in the political and social theories of Hans Morgenthau (on contingency), Herbert Marcuse (on negation), and Eric Voegelin (on noesis), ${ }^{7}$ and showing their relationship to the theme of reversibility in IR. The second section explores the contribution of a concept of reversibility to policy process studies. The purpose of this section is the attempt to explore the possibilities of a philosophical understanding of reversibility for a more practical engagement with politics. Policy process studies have been chosen for such a first step to render a philosophical concept more practical as they make very similar observations of politics. ${ }^{8}$ Their ontological observation (even though they would not term them 'ontological') of nonlinearity and inadvertent action consequences which negate and refute policy planning (Sharkansky, 2002; Weible, 2014; Wilson, 1989; Zahariadis, 2014) is a promising way to bring in reversibility. However, they exclude to account for the epistemological consequences of this observation, disallowing, as will be shown below, for normative thinking. This discussion reveals that policy process studies underplay the question of contingency and non-linearity in politics and that a concept of reversibility suggests an important move in policy studies towards a more reflective and normative understanding of policy processes. The Conclusion develops further questions for a future research agenda, which outline the temporal implications of reversibility and bring in the concept of reversibility into policy-making.

\section{On contingency, negation, and noesis}

\section{On the triangulation of contingency, negation, and noesis}

Thinking in terms of the triangulation of contingency, dialectic negation, and noesis suggests that all three are to be regarded as "gleichursprünglich" ('co-original', in a Habermasian sense; see Habermas, 2008, 1994) for the understanding and analysis of politics. This implies most importantly that they function as co-equal, co-constitutive, and irreducible characteristics of politics. This implies, 
too, that neither becomes dissolved or suspended ("aufgehoben" in a Hegelian sense; Hegel, 1975) in and through the triangulating process. Each remains its full relevance, regardless of whether, or to which degree, each of the other two become temporarily important or emphasised in politics and in political analysis. That is, the notion of contingency continues to describe and capture the ontological situation of the perspectivity and resulting ambivalence of politics; the notion of dialectic negation retains both its ontological and epistemological relevance for revealing the contradiction and (self)refutation of political action and thought; and the apperceiving capacity of noesis defines a grounded form of political judgement which is deeply aware of, and self-consciously comprehends, the contingency and negation of its own and of politics' contexts and horizons.

The triangulation of these ontological, epistemological, and psychological aspects outlines and enables a political ethics which proceeds from the mainly deconstructive notions of contingency and negation/refutation to a positive concept (namely that of reversibility) that orients and guides political analysis and political action. This progression becomes possible through the reflective (self)awareness of the conditions of politics (which is contingent and always potentially negating) through noesis. Noesis helps to break out of the circle of critique and reflection and delivers a reconstructive and rearticulating analytical and practically actionable norm, which orients and guides politics without defining and fixing the content of politics as this would violate and undermine the two other notions of contingency and negation. Noesis drafts theoretical and political openness towards, and apperceiving reflection upon, contingency and negation as intrinsic ontological and epistemological conditions of politics. It thus triangulates contingency and negation and incorporates them into normative political thinking. Through noesis, contingency and negation become thus illuminated and tangible to and for themselves.

The rationale for this triangulation emerges from the argument that if politics and political knowledge are contingent, perspectivist, and negated and thus of deconstructing quality, we need a normative yardstick for rearticulating political order and political agency. And contingency as time- 
space perspectivity and negation as refutability of politics, triangulated with noesis as the reflective capacity on, and rearticulating practical norm of, both result in the practical demand that policies are reversible or at least non-irreversible. The paper turns now to the discussion of contingency, negation, and noesis to specify them in their own right and to be able render their triangulation more precisely thereafter.

\section{Perspectivity and the contingency of political action and knowledge}

“(All) theoretical analyses are contingent upon factors of whose occurrences we either know nothing or whose consequences we cannot foresee" (Morgenthau, 1962a: 70)

Perhaps surprisingly to many in IR, few figures exemplify the importance of contingency better than Hans Morgenthau. There are several threads throughout his oeuvre where Morgenthau stresses that all theory and political action is contingent upon factors of which we had no knowledge, and consequences, which we could not predict and at best can only calculate probabilistically. Drawing on Karl Mannheim's use of the German term 'standortgebunden' to describe the spatial and temporal conditionality of political and social theory and knowledge (Mannheim, 1936; 1984) Morgenthau claims that political theory and action always depend upon the historic and cultural environment in which they have been formulated and in which they are supposed to operate. These terms thus endorse a perspectivist understanding of an object revealing characteristics of itself only in relation to perspectives applied. ${ }^{9}$

Accordingly, all social and political knowledge is historically and spatially contingent. In Morgenthau's probably most cited text, in his 'Principles of Political Realism', we find no less than three paragraphs in which he explains this position. ${ }^{10}$ But also in addition to these statements, he argues explicitly in The Concept of the Political (2012 [1933]) and in 'The Intellectual and Political Functions of a Theory of International Relations' (1962a) for contingency and perspectivity which coin- 
cides with his criticism of the rationalist and positivist ideas of historical progress, techniques of social engineering, and the rationality of the 'Age of Reason'. All of these would all require a universal standpoint of knowledge from which to derive their ideas and respective strategies for their realization. $^{11}$

We thus recognize in Morgenthau's arguments the critical stance of perspectivism towards three prominent theories of knowledge (Behr, 2013). First, it is critical about a rationalist approach to overcome the confinements of human knowledge through the construction of knowledge of the external world out of principles possessed by the mind itself. ${ }^{12}$ Second, this notion is also adverse to an empiricism which would base knowledge about the political world on sensually conceived impressions and which would rely in its assertions about the world on (ostensibly) mind-independent data bruta, i.e. methodologically on positivist quantifications and measurements of social and political phenomena, built on the hope that through inductive logic there may be some day some kind of spillover from data collection to knowledge. (Holt et al., 1960: 152). And third, the notion of perspectivity, because it recognizes the mind-independent, however spatio-temporally qualified status of things real, 'strips mind of its pretensions, but not of its value or greatness (...) [This notion] dethrones the mind, [and at the same time] recognizes mind as chief in the world' (Alexander, 1960: 186). We here further recognize an anti-idealist position against the belief in a 'world in which there exist only minds' (Holt et al., 1960: 154, 155). In this vein, Morgenthau notes:

(Theory) consists in ascertaining facts and giving them meaning through reason. It assumes that the character of a (...) policy can be ascertained only through the examination of the political acts performed and of the foreseeable consequences of these acts (...) Yet examination of the facts is not enough. To give meaning to the factual raw material of foreign policy, we must approach political reality with a kind of rationale outline, a map that suggests to us (...) possible meanings of (...) policy (from the First of his 'Six Principles ...'). 
Therefore, the epistemological underpinning of perspectivism consists in the acknowledgment of the existence of mind-independent political realities in which, however, the mind plays a paramount role in that these mind-independent realities become meaningful only through theoretical understanding. Further to this, these 'facts' are not to be seen as structurally alike, but have to be studied and understood in their contingent spatio-temporal constellations. This epistemological position posits that both the thing-being-observed and the observer mutually influence and constitute each other in the political world and in political analysis (see also Taylor, 1971).

\title{
Dialectic negation and the fallibility of political action and concepts
}

\author{
"(The) process of reality (...) defies formalization and sta- \\ bilization, because it is the very negation of every stable \\ form. The facts and relations that appear in this process \\ change their nature at every phase of the development." \\ (Marcuse, 1941: 144)
}

The second notion involved in developing a political concept of reversibility is the idea of dialectic negation as we know it from Frankfurt School Critical Theory. To develop this idea, I will draw mainly on Herbert Marcuse, particularly from his Negations: Essays in Critical Theory (1968). According to the anti-metaphysical stance of critical theory, i.e., one of the main differences between 'traditional' and 'critical' theory, dialectic negation is targeted against any speculation and assumption about an essence and telos of history, society, and humanity (especially Horkheimer, 1999 (1937)). Against such assumptions, critical theorists stress the study of historical experience and empirical historical inquiry into the genealogy of socio-political transformations. Thus, in the Introduction to One-dimensional Man, Marcuse describes critical theory as the attempt to elaborate historical alternatives to actual pathways of societal developments (1964); and in Negations, he writes: 
Through [critical theory], given facts are understood as appearances whose essence can be comprehended only in the context of particular historical tendencies aiming at a different form of reality. The theory's historical interest enters constitutively into its conceptual scheme and makes the transcendence of 'facts' towards their essence critical and polemic' (1968: 71).

This takes us to the core of critical theory's notion of dialectic negation. To find those historical alternatives and possibilities of their realization, including why certain pathways of historical development have dominated over others, historical inquiry is linked to the ideas of emancipation and liberation. The awareness and elaboration of historical alternatives and potentialities underline humanity's potential in relation to social, political, and economic conditions. Here, Marcuse speaks to us as if he were driven to rescue some of the Enlightenment promises so pessimistically dismantled by his peers Theodor W. Adorno and Max Horkheimer (in their Dialectic of Enlightenment, 1981 [1944]). This road to permanent and always possible negation and alternatives leads to the notion of 'dialectic'. Marcuse writes:

Materialist theory thus transcends the given state of fact and moves towards a different potentiality, proceeding from immediate appearance to the essence that appears in it. But here appearance and essence become members of a real antithesis arising from the particular historical structure of the social process of life. The essence of man and of things appears within that structure; what men and things could genuinely be appears in "bad", "perverted" form. At the same time, however, appears the possibility of negating this perversion and realizing in history that which could be. This antagonistic character of the historical process as it is today turns the opposition of essence and appearance into a dialectical relationship and this relationship into an object of the dialectic (1968: 67).

The idea of dialectic negation thus relates not only to material, historical events, but also and importantly to the awareness and consciousness of the theoretician. Dialectic negation comprises an ontological and an epistemological dimension because the theoretician not only studies historical 're- 
alities' and 'potentialities', but needs to be aware of and self-consciously build in a dialectic of their own argument. The relation between thesis and anti-thesis and their permanent forward-drive is of both materialistic and intellectual character. This means that we as researchers and political agents need to be always aware of the potential and actual negation of our own argument and should even push and develop our own arguments towards their limits and finally their own negation. In 'Traditional and critical theory', Horkheimer, too, briefly reflects upon the role of the theorist:

(The person of the theoretician) exercises an aggressive critique not only against the conscious defenders of the status quo, but against distracting, conformist, or Utopian tendencies within his own household (1999: 214).

However, critical theory goes further and argues that the theoretician is in a position to experience historical potentialities that have never been realized. This envisioning seems only possible through a proactive dialectic forward-development of the own theoretical argument and analysis that negates itself as soon as it is made. And indeed, this seems to be the idea when Marcuse writes: 'Reality is overcome by being comprehended as the mere possibility of another reality' (1968: 83). For the development of a political concept of reversibility, Marcuse's perception of the theory-practice relation is important. In Negations he writes:

What, however, if the development outlined by the theory does not occur? What if the forces that were to bring about the transformation are suppressed and appear to be defeated? Little as the theory's truth is thereby contradicted, it nevertheless appears then in a new light which illuminates new aspects and elements of its object' (Ibid.: 142).

Irrespective of this problematic statement on the relation between theory and practice, the notion of dialectic negation encourages the theoretician, finally everyone, to be aware of the permanent negation of politics and of the likewise permanent counter-possibility of one's own argument. This notion therefore includes the necessity of permanent self-criticality and refutability as either a concurrent aspect within or as a procedural aspect subsequent to one's own argument and political action. 


\section{The normative triangulation of perspectivity and negation with noesis}

"The center of a (practical) philosophy of politics (is) a theory of consciousness [of order in which] nous symbolizes the human experience of order" (Voegelin, 1978: 3-5)

The arguments about space-time-contingency of political knowledge and agency as well as of negation need to be complemented and framed within the notion of noesis. Voegelin elaborates the notion of noesis going back the distinction between, on the one side, knowledge and prudence and doxa and opinion on the other in Plato's Sophistes and Aristotle's discussion of intellectual virtues in Book VI, Chapter V, Nichomachean Ethics. How does this relate to contingency/perspectivity and negation? Fundamentally, noesis, informed by knowledge and prudence, is a principle for the normative formulation of politics which triangulates perspectivist and dialectic critique. According to Aristotle, prudence (also translated as practical wisdom, practical judgement or phronesis) has to do with practice and the variable, is therefore mainly concerned with knowledge of particular and contingent facts (Ibid. 1141b15). It is thus a practical, normative principle which accounts for contingency and negation/refutability. However, while noesis provides normative direction, this direction needs again to be qualified. And this qualification is accomplished by perspectivity/contingency and negation. The noetic articulation of politics thus needs itself a mechanism of critique that is built-in this normative articulation itself and which consists of perspectivity and negation. But what exactly does Voegelin mean by noesis?

Noesis is an intellectual operation, accounting for 'the variable' and the particular, that critically reflects upon the degree - and creates an awareness of this degree - to which political order, its institutions, and its symbols correspond to humanity as the anthropological constitution of politics. Thus, noesis is a device of political judgment that is aware of, and judges whether, or not, political action and policies violate or apprehend humanity. But as what is humanity imagined? Voegelin refers to an intellectual figure which he calls in neo-Aristotelian language the 'divine ground of exist- 
ence ${ }^{13}$ according to which human existence and politics is perceived as tension between existential questions that are neither tangible, nor answerable; sometimes they are not even effable. ${ }^{14}$ Such intangibilities and ineffabilities are not a deficiency of a dark age or of a not yet fully developed consciousness. They are rather indicating the fundamental human condition of the intellectual and practical limitations of contingent and perspectivist human knowledge, action, and politics; i.e., there will always be unanswerable questions of human and political life, and subsequently uncontrollable and non-manageable political conditions and consequences. According to Voegelin, this is to be acknowledged and respected (apperceived) and not to be violated by knowledge claims that pretend to have definitive answers. This is Voegelin's main argument against political ideologies and of all politics, respectively, that would become ideological precisely when and if they promote knowledge claims that pretend to have final answers as to the meaning of politics and history and that pursue policies based on such claims (1999 [1938]). 'The refusal to apperceive', Voegelin notes, 'has become $[\ldots]$ the central concept for the understanding of ideological aberrations and deformations' (2006: 125). Subsequently, it is crucial for responsible politics to be aware of the tension of human beings' existence as living in a spectrum of intangibilities and ineffabilities and to not attempt to dissolve this tension by claiming final answers and by acting upon them (Voegelin, 2006: 98).

The awareness and consciousness of such tension as the fundamental human condition is what Voegelin calls noetic 'apperception'. Thus, apperception results from the experience and awareness of the human condition. Further to this, apperception can recapture humanity in politics through this awareness and its emphasis in the case of politics that violates the human condition.

Recapturing reality in opposition to its contemporary deformation requires a considerable amount of work. One has to reconstruct the fundamental categories of existence, experience, consciousness, and reality. One has at the same time to explore the technique and structure of the deformations that clutter up the daily routine; and one has to develop the concepts by which existential deformation and its symbolic expression can be categorized (Voegelin, 2006: 121). 
Rehearsal: the triangulation of contingency, negation, and noesis and the politics of reversibility

The discussion of contingency, negation, and noesis leads to three insights. Contingency includes the time-space-perspectivity of political knowledge and the socio-political embeddedness of political theory and action. The notion of negation includes, too, a theoretical and practical proposition. This proposition holds that there is always another, a next viewpoint and thus no absolute certainty about, and finality of, one's own theoretical and political view and practice; i.e., 'clinging to any one position would commit error because of the intrinsically limited viewpoint of any one subject, which in turn suggested the necessity of engaging with opposing ways of thinking' (Brincat 2014: 590). Consequently, this proposition leads to the necessity of an inherent and permanent critique towards own theories and practices and reasons the crucial awareness of the refutability and fallibility of one's own approach. This might be because of concrete historical alternatives or counter-arguments to actual political strategies. This proposition hence includes the demand that the theoretician and the politician should always procure for and anticipate alternatives and to account for this in his/her theoretical views and political actions. And noesis stresses the prime status of human experience of politics, emphasising the significance of uncertainties, indeterminacies, and contingencies as well as the analytical awareness of whether, or not, political order corresponds to human experience. Put differently, political order and policies need to resonate with human experience that is always the experience of an indeterminate, contingent, self-refuting, and fallible political world.

The notion of noesis does include the Aristotelian concept of phronesis as a grounded form of political judgement that is aware of its own limited context and horizons as also argued by David M McCourt (2012). However, contrary to McCourt's understanding who rightfully stresses the aspect of pluralism, of deliberation, and of phronesis as a form of knowing, phronesis does, as he perceives it, not consist in a distinct political strategy or decision. In contrast, phronesis is primarily a device of practical judgement of political action which, in order to account for pluralism, contingency ('the 
variable' in Aristotle's terminology) and negation, is less oriented towards substantive decisions and a political prescription of what would be prudent, and what not, but rather, precisely because it accounts for contingency and negation, in excluding certain forms of political conduct and political action from being prudent. What is prudent, and what not, is thus a quality of political conduct acting in such a (in a particular) way so that action consequences would not contradict contingency and negation, with, however, no specific prescription or definition of the content of politics. In this vein, Aristotle argues that phronesis is not about producing things/politics (Nicomachean Ethics, 1143b27).

But noesis also includes another important element of phronesis, namely the emphasis on the particular, the situational, and the contingent as also Martha Nussbaum stresses when she speaks of the 'priority of the particular' in Aristotle's phronesis (1990: 66; also Devereux 1986). This element also plays an important role in Bent Flyvbjerg's conceptualisation of phronetic planning research (2004). Flyvbjerg links Aristotelian phronesis with mainly Friedrich Nietzsche and Michel Foucault because a contemporary concept of phronesis would need to incorporate "power", absent in Aristotle (so Flyvbjerg 2001, Chapters 7, 8). However, since it seems he is mainly concerned with theoretical and methodological questions of research and not with political action and policy-making, it remains finally unclear whether phronesis, according to Flyvbjerg, is a quality of political agency, which guides, or should guide, action, or of the researcher which should guide research studying the particular and contingent. Because of this unclarity, his conceptualisation is of limited use for the argument here; however, important for the conceptualisation of reversibility and its triangulation of noesis with contingency/perspectivity and negation/refutability remains the interpretation that phronesis is aware of the particular, pluralist, and contingent element of politics. This is important to finally specify noesis as partially similar, but also distinct from phronesis.

While the phronimos, i.e., the one who possesses phronesis, is self-aware and reflective of acting with moderation in a pluralist and contingent environment with attention to the particular (or at least of the norm to act in such a way), phronesis does not include the analytical awareness of 
whether, or not, in the bigger picture certain policies and political reality account for contingency/perspectivity and negation/refutability as noetic 'apperception' does. Thus, noesis includes phronesis, but goes a decisive step beyond individual action in that it includes an analytical capacity of political order as a whole (also Corey 2002: 57; 72, 73). However, it also needs to be qualified, or 're-engaged' in light of 'particular actions, policies, constitutions, and so forth' (ibid.: 68, 71), a task which the notions of contingency/perspectivity and negation/refutability provide. Yet, while negation suggests ceaseless critique - 'a perennial method of criticism' (Adorno 2006: Nr. 152), developed in IR by Daniel Levine (2012) and Shannon Brincat who writes that dialectics 'incessantly abuts, confronts, and attempts to sublate those dominant ways of thinking' (2014: 589), emphasised here through the permanent dialectic forward-drive of argument and counter-argument according to Marcuse, finally resulting in negation's refutability and self-refutability of political action and political views $^{15}$ - this deconstructive activity is not sufficient in itself to answer the question of responsible and ethical political agency and thus needs again qualification. It is not sufficient because ceaseless criticism is a mainly theoretical activity, which needs some kind of breakthrough and cut-out into action and therefore needs the introduction of a qualifying normative and reconstructive moment. Such a moment it receives through noesis's reflective and apperceiving awareness of, and judgment about, the existence of humanity and of the prime role of human experience in political order.

This role of human experience, so demands triangulation, must, however, not only be qualified and eventually constrained by dialectic negation, but also by contingency and perspectivity. These notions situate each theoretician and the politician within a distinct historical context and event horizon, which not only must be critiqued, but also explains the very position(s) held and advanced in academic debates and in the political arena. This crucial insight from Mannheim's sociology of knowledge and its adoption by Morgenthau (as discussed above) is a crucial understanding of theory and practice in 'reflexive realism' which needs (again) practical orientation (see for this re- 
quest the Special Issue by Behr/Williams, 2017; also Steele, 2007, as well as Harraway, 1988; Hoeber-Rudolph, 2005).

As we have seen, no single notion - neither contingency, nor negation, nor noesis - is sufficient in and for itself for outlining responsible and ethical politics; each needs to be qualified through the two other notions. For practical political action, the mutual qualification of these notions through triangulation yields a concept of political reversibility: If the consequences of political action (and policy making) cannot be predicted due to the contingent character of the political and human world, and, furthermore, are historically and intellectually refutable (even self-refutable) due to dialectic negation, it appears as irresponsible to enact policies which materialise in eternal or set-in-stone consequences and thus contradict contingency and negation. Responsible political action - which is responsible precisely as, and only if, it accounts for and is, through apperceiving reflection, aware of contingency and negation as intrinsic conditions of politics - must hence act only in such a way that its consequences are at least partially reversible and can be turned back if found to violate the principles of contingency and negation. This practical conclusion through triangulation can be further specified through Marcuse's discussion of negation:

Only such a mode of existence can incorporate the negative into the positive. Negative and positive cease to be opposed to each other when the driving power of the subject makes negativity a part of the subject's own unity ... This is the mode of being or existence that Hegel describes as 'real infinity.' Infinity is not something behind or beyond finite things, but is their true reality. The infinite is the mode of existence in which all potentialities are realized and in which all being reaches its ultimate form (Marcuse, 1941: 69).

The benefit of triangulation becomes immediately visible here as it enables us to see the potentialities of all 'things' unravelled through 'real infinity', but - rendered comprehensible only through triangulating negation with contingency and self-reflective and apperceiving awareness - also their limitation and context-dependency as all 'things' are never finite and ceaselessly develop towards and 
into an unknown future. This is a situation which action-theoretically can be accounted for only through avoiding the creation of 'things' (speak: policy consequences) which were determined, static, or fixed, thus only through reversibility.

In order to examine these philosophical ideas in their significance for empirical-practical political analysis, the next section will discuss possible avenues of these philosophical notions into policy studies, illustrating the application and transferal of these philosophical notions to empiricalpractical analysis. This is not an attempt to ground contingency and negation beyond the philosophical discussions above in international policy analysis, but rather an effort to find out about the possible contributions which international political theory can make to policy analysis; and, through exploring such an avenue, to provide guidance and orientation in both policy analysis and finally in policy-making.

\section{Bringing the concept of reversibility into policy studies}

Irrespective of epistemological differences between the previous discussions and the understanding of theory in policy process studies as causal, explanatory, and falsifiable as well as hypothesesgenerating, ${ }^{16}$ this section makes the attempt to reflect upon possibilities of how the concept of reversibility can contribute and relate to policy research, taking the common claim for the need of multiple theories seriously (see e.g. Cairney, 2012; Sabatier, 1999; Weible, 2014).

An avenue for such a bridging is the common observation within policy process studies of the messiness, uncertainty, and ambiguity of policy processes. Ambiguity refers, according the Martha Feldmann, to 'a state of having many ways of thinking about the same circumstance or phenomena' (1989: 5) and is seen as an essential and inescapable characteristic of the policy process. In this vein, James Wilson makes us aware that more information may reduce uncertainty (1989: 228), however, does not abolish ambiguity. And Christopher Weible writes in an overview over the legacies and current challenges of policy research that '(if) anything has endured regarding the study of policy pro- 
cesses, it has been an understanding that these phenomena are messy and that theory is necessary to help disentangle them'. ${ }^{17}$ Echoing this, Nikolas Zahariadis speaks of 'organised anarchies', and with reference to Ira Sharkansky (2002) not only emphasises the importance of contingency in and of policy processes, but also argues that 'decisions are made as the process unfolds, and they may even be facilitated by opaqueness' (Zahariadis 2014: 27).

Zahariadis belongs to the group of policy researchers who promote the contingency notions of policy processes the most. This group argues - as he does with regard to the Multiple Streams Approach (MSA) - for a so-called 'post-positivist' opening of policy studies that, echoing one of the main problematics discussed in the first section of this paper, stresses the 'unintended consequences' of policies and policy processes (Schneider/Ingram/Deleon, 2014: 27).. Next to the Multiple Streams Approach in this regard are the social constructivist Democratic Policy Design-approach (see for example Schneider/Ingram/Deleon 2014; Saurugger, 2013) and the Narrative Policy Framework (McBeth/Jones/Shanahan, 2014; Shanahan/Jones/McBeth/Lane, 2013).

However - and this is in line with the scientific demands of policy research and their understanding of theory as explanatory, as external to the reality studied, and thus as abstract as possible from this reality (Sabatier, 1999: 266) - such awareness has so far failed to generate ontological reflection on the reality studied, i.e., on the policy process, nor to debates on how such reflection would epistemologically inform theory and analysis. Indeed, policy research seems to deliberately push aside ontological and epistemological discussions and 'takes a purely pragmatic approach' as Mark McBeth, Michael Jones, and Elizabeth Shanahan argue ${ }^{18}$ in their immediate response to postpositivist critiques of their Narrative Policy Framework by Geoffrey Dudley (2000) and Wayne Parsons (2000). Consequently, contingency criteria are incorporated only as variables of model-building into policy theories that themselves have to be causal, consistent, and 'clear enough to be wrong'. A subsequent demand is that methods and research technologies have to be developed that provide information about a messy and contingent world, however, in causal and consistent ways. This appears 
as the squaring of a circle. A good example here is the Narrative Policy Framework and its incorporation and operationalisation of policy narratives as social constructions. Such incorporation occurred subsequent to 'post-positivist' influences in policy research. Interesting is, however, how McBeth, one of the founders of the framework, works the idea of narrative into his policy framework.

McBeth et al. write that 'until very recently in public policy scholarship, the lack of adherence to scientific standards was viewed as necessary to study the role of narrative in politics and policy. Infused with subjectivity and relativism, as recently as 2005 , the study of narrative was declared incompatible with such scientific standards as validity and reliability' (Shanahan/Jones/McBeth/Lane, 2013: 454; see also Dodge/Ospina/Foldy, 2005: 287). Narrative was seen as a component of policy processes that could not be operationalised in causal and explanatory theories due to its subjective, relativistic, and contingent nature. What became at stake here was the contested nature of 'facts' between data bruta and social construction as well as of appropriate methodological tools for their study, followed by the question of what is 'science' and what counts as 'knowledge'. Thus, this issue reached to the core of understanding research and the relation of the researcher to his/her world of study. Consequently policy research should take a reflective pause (yet another reflective pause, so to say, alluding to McBeth's recent request and metaphor (2014: 454)), taking their contingency observations more seriously. And this would mean to not only treat them as variables which have to be operationalisable, quantifiable, and measurable, but rather to question whether their own contingency observations have epistemological implications on the kind of knowledge that they can achieve about (this) reality.

I suggest that such a reflective pause can bring new awareness in policy research about the relation between their 'object' and its study as well as about the shaping of this object through the researcher. Such awareness would open-up the possibility of going beyond explanatory theory and the dominant question of how something happens in the policy world, to also address the question of what should and should not happen. This must not be a manual or prescription for policy, but would 
explicitly provide normative orientation both for policy-makers and for a framework for the assessment of policy. Such an orientation is suggested through the concept of reversibility, i.e., through the contribution of noesis in triangulation with perspectivity and negation.

Such a move to normativity does not seem foreign to policy research (Weible 2014: 391), ${ }^{19}$ however, it is only implicitly inherent whereas I am asking for a more conscious and explicit elaboration of it. Thus, we need to ask what kind of policy is needed to accomplish social salience and to finally guarantee a democratic policy, without, however, becoming prescriptive? The notion of noesis, as explained above, triangulated with perspectivity and negation, can help us answer this question. Since the notions of contingency and of negation echo observations of perspectivity, context, and ambiguity of the research field, this acknowledgement has two political consequences: first, they demand ontological and epistemological humility as our primary relation to the world and translate politically into a politics of reversibility, which demands to not enact policies with non-irreversible consequences. And, as argued in the first section, this position, second, needs some reorientation and normative embedding which must not prescribe or develop a political manual as this would undermine the contingencies of the policy world, the inherent refutability of concepts, and the falsifiability of hypotheses about it. Such reorientation and embedding is provided by noesis as it articulates politics and political agency without fixing the content of politics, but rather is reflective of, and pragmatically guided by, the intrinsic characteristics of the political action field as contingent and negated.

\section{Conclusions}

This leads to the development and outline of further research questions for a research agenda at the crossroads between political philosophy in IR and policy research. The main foci are two: first, the concept of reversibility has to be further elaborated through an engaged, critical dialogue with policy research. Second, the concept of reversibility needs to be further developed concretely in close coop- 
eration with policy-makers, be they state, intergovernmental, or NGO actors. Such a research agenda includes questions such as: How does a concept of reversibility translate into policy design and policy implementation? Are institutional mechanisms conceivable which would prevent consequences which harm contingency/perspectivity and negation and take effect when, and as soon as, such consequences occur? Are such institutional mechanism accompanied, supported and facilitated by an ethical habitus of reversibility? Mechanisms to institutionalize reversibility need to respond to deferred and complex time dimensions of the manifestations of consequences while at the same time apperceiving when and if such consequences solidify as irreversible. Thus, the persuading strength of reversibility plays out not in political trade-offs, but is based upon political ethics and institutional arrangements. As an important part of reversibility relates to the complexity and differentiation of action consequences and their unfolding as hinted at by policy process studies, an elaborated analysis of the time horizons of policy consequences is among the immediate further conceptual tasks. I can here only outline such an elaboration which has to focus on mainly two time dimensions.

First, and subsequent to political action and policy implementation, reversibility appears $a$ posteriori as 'directional malleability' (Tymieniecka, 2009: 39) or pliability of policy consequences, with the awareness, however, of never being able to overcome contingencies, ambivalences, and inadvertent consequences. Metaphorically, reversibility corresponds with the idiom 'between Scylla and Charybdis' derived from Homer's Odyssey (for this metaphor, see Steinberg, 2014), having to choose between two evils, but deciding for the lesser evil by rectifying and mitigating irreversible consequences through guidance provided by the triangulation of contingency/perspectivity, negation/refutability, and noesis. Second, reversibility also functions as an a priori reflection and ethical constraint for responsible political action and policy-making, which demands humility facing ever existing uncertainties and inadvertent consequences of politics. With regard to an a priori reflection, a political concept of reversibility can learn from Environmental Sciences (inter alia Palumbi/McLeod/Gruenbaum 2008) and Economics where the term 'reversibility' is discussed with 
regard to the insights that policy consequences can and should, if not be inverted to an original status quo ante then at least be partially reversible. This is illustrated best in economics discussions of the conditions for successful investments and the contingency and unpredictability of market contexts and consumer behaviour why not only the strategies, but also their consequences should be reversible. Also, these discussions emphasise, just as policy process studies, that action consequences do not unfold en bloc and all at once, but in sequential and non-linear series (Andrew/Eberly, 1994, 1996; Patillo, 1998; Ramsey and Rothman, 1996).

The a posteriori and a priori distinction of the temporal dimension of reversibility is helpful for a further specification of the concept. This distinction can be related to contemporary discussions in IR about time and the basic distinction in the Greek notions of chronos and kairos (Hom, 2018a, b; Hutchings, 2008), i.e., between the notion of time as linear and chronological (also termed 'homologous empty time'; Anderson, 1983) and time as seen through the language of contingency and the unexpected, surprising event (as exemplarily problematised by Plutarch in his Moralia, 'The Obsolescence of Oracles'). While in its a posteriori-dimension reversibility can look back in hindsight at consolidated consequences and can assess (even though not in total as they are always in a process of still unfolding) their conciliation with contingency/perspectivity and negation/refutability, and if necessary rectify and mitigate their impact, it sits with chronos. In its a priori-dimension as actiontheoretical ethics and the avoidance of future consequences which harm contingency and negation/refutability, reversibility sits with kairotic time and its emphasis of sudden, unexpected, and unpredictable events. The further discussion of these themes would also include the question of how this relates to the notions of 'advent' and 'event' in Jacques Derrida (see amongst others the discussions in Behr, 2014: 109-112).

Before further research in these complexities and in the questions outlined above, it has been necessary, however, to establish the conceptual foundations of a political concept of reversibility of which two philosophical guiding principles - the perspectivity and contingency of politics and the 
inherent potentiality of the failure and of inadvertent consequences of each concept and action - resonate with policy research. This observation, complemented with the notion of noesis, paved the way for a conversation on political ontology and its epistemological effects between political philosophy in IR and policy research, making space for, and attempting to bring in, explicit normative thinking into policy studies.

The two basic demands resulting from reversibility are, briefly summarised: First, a political ethics which is informed by, and upholds, the importance to consider global policy consequences in light of their reversibility and subsequently to avoid policies which have non-irreversible consequences as they would contradict intrinsic human conditions of politics. One might counter that this leads to rather passive politics; and yes, this is precisely what a concept of reversibility would hold, finally propagating humility rather than activism. And the remedy for already impacting irreversible consequences of past politics would not be further non-irreversible policies with the hope to turn back previous consequences, but to develop policies which mitigate and absorb previous nonirreversible consequences. The concept of reversibility thus promotes an ethics of avoidance of further, the stop of enacted, and the mitigation of previous harm through irreversible consequences, based on political humility in the face of political contingencies, inadvertencies, and ever unstable political existence; not of the idea that caused harm could be undone by, possibly again nonirreversible activist politics. Such political ethics of reversibility as responsible politics should - I may conclude here, but further discussion on public deliberation would be needed - not only guide policy-making, but public political discourse in general.

The second demand results in transnationally and globally institutionalised mechanisms in political decision-making and policy-implementation that interfere when non-irreversible policies are being enacted and which bring such enacting to a pause and possibly still stand. A careful assessment of the impact and the consequences of policies is needed here triggering the intervention of such mechanism, such as qualified majorities or vetoes, which would function as both pre-emptive (i.e., 
interfering due to an immediate risk of non-irreversibility) and preventive (i.e., alerting to and deterring the possibility and likelihood of such risks) institutional arrangements. Such awareness and alertness requires politically the widest possible inclusion and empowerment of people conceivably concerned and harmed by certain policies, irrespective of national politics, borders, and citizenship. ${ }^{20}$ However, these are just outlines, and, as noted above, the concrete elaboration of such mechanisms needs the intense cooperation between political philosophy, policy research, and policy-makers, which this paper hopes to contribute to. 


\section{Acknowledgements}

An early version of this paper has been presented at the first workshop of the Responsibility-network at Durham University in June 2017, thus many thanks go to Richard Beardsworth and Anthony Lang for their invitation. Further thanks go to several people who have read and helpfully commented upon later versions, namely Jemima Repo, Matt Davies, Michael C. Williams, Valerie Pellat, and the participants of the Research Colloquium at Politics, Newcastle University. I also want to express special thanks for the very careful and attentive comments of two reviewers whose critique has helped a great deal to shape and strengthen the argument of the paper.

\section{Notes}

1 See also the panel "30 Years of Critique: Critical Theorising and World Politics" at the 36th Annual Conference of the British International Studies Association BISA in Manchester (UK), 28th April 2011; also Yalvaç, 2015.

2 To the spectrum of contemporary political and social theories received in critical IR belong most importantly authors such as Arendt, 1958; Adorno, 1973 [1966]; Butler/Laclau/Zizek, 2000; Derrida, 1993; Habermas, 1994 [1968]; Hardin 2003; Rorty, 1989; Simmel, 1977; Schütz, 1972; Taylor, 1989; Nason 2012; Connolly 2011.

3 Ethics is here understood according to Zygmunt Baumann as critical reflection on the conditions of political judgement. Such critical reflection, as will be argued and developed here, consists of the triangulation of contingency, negation, and noesis, and subsequently to act politically following the concept of reversibility.

4 This claim is shared with many ideology-critical discussions, debated in the literature as 'pejorative' understandings of ideology (as in Voegelin, 1938; Morgenthau, 1946; Arendt, 1951). 
Also Derrida's notion of “aporia" suggests the opening-up of intellectual and social spaces, keeping them unoccupied, against the foreclosure through ideologies and their essentialism (see Derrida, 1992, 1997, 2007; for a further interpretation see Behr, 2014).

5 Important is here the aspect that consequences can never be revised to some original status quo, but only partially. Therefore, I will occasionally use in the following for the lack of a better term the admittedly non-elegant language of non-irreversible consequences, rather than 'reversibility' which might suggest the total revision of consequences.

6 In political science and International Relations I encountered only six literal references to "reversibility" (Gallop, 2006; Galtung, 2003; Hamilton/Hamilton, 1983; Joppke, 2005; Pridham, 2007; Young, 1994); yet, as these writings and individual discussions revealed, their authors do not conceptualise this term, but use it in its colloquial meaning of reciprocity and inversion. Extending the research into the wider field of social science disciplines shows that the same colloquial meaning seems to prevail in the likewise peripheral use of this term in, for example, technology (Introna, 2007), anthropology (Alberto/Willerslev, 2007), psychology (Neisser, 1973), religious studies (Mou, 2004; Yagi, 1982), performing arts (Kozel, 1995), moral (analytic) philosophy (Brook, 1987; Henson, 1973), or phenomenology (Dillon, 1983; Sarukkai, 2002; Stawarska, 2002).

7 Hans Morgenthau and Herbert Marcuse are amongst the earliest post-WWII social scientists to make the commitments of contingency and negation in an explicit, precise, and practically-oriented way. This is the reason why they have been selected here, being aware that they are, of course, not the only authors from whom these notions could be elaborated. But their work significantly helps to sharpen these concepts (see also Behr, 2017). And Eric Voegelin is amongst the most prolific contemporary authors on Plato and Aristotle and their notion of noesis. In methodological terms, it is worth noting that I do neither aspire, nor claim, nor deem possible a truthful and authentic representation of named (and other) authors, rather than reading them hermeneutically as inspiration to en- 
gage a certain problematic which the paper shares with them, following the idea of symptomatic reading (see Althusser, 1965; Behr, 2014; Rooney, 2017).

8 Thinking of a bridging exercise between philosophy in IR and policy-oriented literature, it would be interesting also to ask in how far approaches of policy learning (e.g. Rose 2005), policy change, and policy dismantling (e.g. Bauer/Knill, 2014; Jordan et al., 2013) or the neo-functionalist concept of spill-back (see inter alias Schmitter 2002 [2003]) may account, though they not use the term 'reversibility', in different ways for possibilities of reversion. For reasons mentioned, this paper focuses on policy process studies.

9 Morgenthau and Classical Realism in general stand here under the influence and in the legacies of Nietzschean thinking about 'objectivity' and the relation between observer and the-thing observed in the humanities and social sciences; see Nietzsche, 2003; Frei, 2001; the Introduction to Morgenthau, 2012.

10 See in his Politics Among Nations from the 1954-edition onwards; for a deeper discussion of contingency in Morgenthau’s writings see also Williams, 2004.

11 Further to his published oeuvre, including Scientific Man vs. Power Politics (1946) and 'Reflections on the state of Political Science' (here 1962b), we have additional evidence from his 1952-lecture 'Philosophy of International Relations' as well as from letters between Morgenthau and Karl Gottfried Kindermann from the 1960s; see Morgenthau Archive, Law Library, Library of Congress Washington, Box 33.

12 For this realist epistemological position, see Feldman, 1999: 93: 'The application of the general idea of context dependence to knowledge attributions is straightforward. What it takes for a knowledge (...) to be true can vary from context to context'; see also DeRose, 2009; Feldman, 2001. 13 In this German writings Voegelin terms this "Spannung zum Grund"; for the English version see (2002) 'What is Political Reality?'. 
14 We read: 'The tension toward the ground is the material structure of consciousness but not an object of propositions; rather it is a process of consciousness having degrees of transparency for itself. In the noetic experience, consciousness attains its optimum luminosity in which the tension toward the ground can interpret its own logos' (“What is Political Reality?”, 2002).

15 It is an interesting question in how far this claim resonates with Derrida's notion of 'erasure' (Anderson 2012).

16 See for example Cairney/Heikka, 2014; Sabatier, 1991; Weible, 2014; Zahariadis, 2014. The guidelines for theory, according to Sabatier (1999: 266), include 'be clear enough to be proven wrong', 'make the concepts of the framework/theory as abstract as possible', 'develop a coherent model of the individual', 'work on internal consistencies and interconnections', 'think causal process', ' develop a long-term research programme ...', and 'use multiple theories if possible'.

17 Weible, 2014: 392; see also and already Charles Lindblom (1968: 4): "We are going to look at policy making as an extremely complex analytical and political process to which there is no beginning and no end, and the boundaries of which are most uncertain."

18 McBeth/Jones/Shanahan, 2014: 226. See hereto already Harold Lasswell and Abraham Kaplan 1950: 'Our aim ... is not to rewrite ... manuals [of political action] but rather to elaborate a conceptual framework within which inquiry into the political process may fruitfully proceed' (Lasswell and Kaplan, 1950: ix-x).

19 So does Christopher Weible in his concluding chapter of Theories of the Policy Process write that policy research is and should be 'broad in scope and salient for society' (2014: 391). This formulation reveals the idea that policy research contributes to the well-being of society. However, there is no clarification of, or reflection upon, the democratic nature of policy as such, but this seems to be a silent presupposition (see also Schneider/Ingram/Deleon, 2014).

20 An example might be the law case "State of Hawai'i and Ismail Elshikh vs. Donald J. Trump" that declared Trump's executive order 'Protecting the Nation from Foreign Terrorist Entry into the 
United States" from January 27, 2017 as unconstitutional (see Case 1:17, CV 00050-DKW-KSC from March 15, 2017) and based its dismissal on the argument of the avoidance of 'irreparable' and 'irrevocable' consequences for large parts of the American and of migrant populations. This judgement and its justification seems guided by a noetic reflection on humanity linked with the unforeseeable nature of policy consequences on people and humanity (see the self-reflections on the judgement $28 / 43 ; 32 / 43 ; 38 / 43)$. The decision addresses both identifiable consequences and rectifies those a posteriori (e.g. with regard to consequences for HE/the University of Hawaii with regard to fees) and possible future consequences, thus a priori, with regard to "intangible impacts" (17/43) and "irrevocable damage on personal and professional lives" $(18 / 43 ; 28 / 43 ; 40 / 43)$ as well as regard to future possible uncertainties for international travel (20/43), tourism and family union.

\section{References}

Adorno TW (1973 [1966]) Negative Dialectics. London and New York: Routledge.

Adorno, TW (2006) Minima Moralia. London: Verso.

Adorno TW and Horkheimer M (1981 [1944/1947]) Dialektik der Aufklärung. Frankfurt: Suhrkamp.

Anderson B (1983) Imagined Communities. Reflections on the origin and spread of nationalism. London and New York: Verso.

Anderson N (2012) Derrida. Ethics under Erasure. Continuum Studies in Continental Philosophy, London etc.: Bloomsbury Academic.

Andrew B A and Eberly J C (1994) A Unified Model of Investment under Uncertainty. American Economic Review 84 (1): 1369-1384.

Andrew B A and Eberly J C (1996) Optimal Investment with Costly Reversibility. The Review of Economic Studies 63 (4): 581-593. 
Alberto J C and Willerslev R (2007) An Anthropological Concept of the Concept: Reversibility among the Siberian Yukaghirs. The Journal of the Royal Anthropological Institute 13 (3): 527544.

Alexander S (1960) The Basis of Realism, In: Chisholm R (ed) Realism and the Background of Phenomenology, Illinois: Free Press of Glencoe, pp. 186-222.

Althusser L (1965) Lire le capital, Paris: Maspero

Anievas A (2016) History, theory, and contingency in the study of modern international relations. International Theory 8 (03): 468-480.

Arendt H (1951) On the Origins of Totalitarianism. New York: Schocken Books.

Arendt H (1958) The Human Condition. Chicago: The University of Chicago Press.

Aristotle (2009) The Nichomachean Ethics. Oxford World's Classics, Oxford: Oxford University Press.

Bauer M W and Knill Ch (2014) Understanding Policy Dismantling: An Analytical Framework. In: Bauer MW, Jordan A, Green-Pederson C, Heritier A (eds) Dismantling Public Policy. Preferences, Strategies, and Effects, Oxford: Oxford University Press, pp. 30-56.

Baumann Z (1993) Postmodern Ethics. Oxford/UK and Cambridge/US. Blackwell Publishers.

Behr H (2013) Common Sense, Thomas Reid, and Realist Epistemology. International Politics 50 (6), 1-15.

Behr H (2014) Politics of Difference. Epistemologies of Peace. London/New York: Routledge.

Behr H (2017) Conditions of critique and the non-irreversibility of politics. Journal of International Political Theory 13 (1): 122-140.

Behr H and Williams M C (eds) (2017) Interlocuting Classial Realism and Critical Theory: Negotiating 'Divides' in International Relations Theory. Special Issue Journal of International Political Theory 13 (1). 
Brook R (1987) Justice and the Golden Rule: A Commentary on Some Recent Work of Lawrence Kohlberg. Ethics 97 (2): 363-373.

Brincat, S (2014), Dialectics and World Politics: The Story so Far .... Globalizations 11 (5): 587 604.

Butler J, Laclau E, and Zizek S (2000) Contingency, Hegemony, Universality. London/New York: Verso.

Cairney P (2012) Complexity Theory in Political Science and Public Policy. Political Studies Review 10 (3); http://journals.sagepub.com/doi/abs/10.1111/j.1478-9302.2012.00270.x\#

Cairney P and Heikkla T (2014) A Comparison of Theories of the Policy Process. In: Sabatier P A and Weible C (eds) Theories of the Policy Process, Westview Press: Boulder: Colorado, pp. 363-390.

Connolly W (2011) A World of Becoming. Durham/NC: Duke University Press.

Corey D C (2002), Voegelin and Aristotle on Nous: What Is Noetic Political Science? The Review of Politics 64 (1): 57-79.

DeRose K (2009) The Case for Contextualism. Oxford: Oxford University Press.

Derrida J (1992) The Other Heading. Reflection on today's Europe. Bloomington: Indiana State University Press.

Derrida J (1993) Aporias. Stanford: Stanford University Press.

Derrida J (1997) Deconstruction in a Nutshell. A Conversation with Jacques Derrida. Edited and with a commentary by John D. Caputo, New York: Fordham University Press.

Derrida J (2007) Psyche. Inventions of the Other. Volume I, Stanford: Stanford University Press.

Devereux DT (1986) Particular and Universal in Aristotle's Conception of Practical Knowledge. Review of Metaphysics 39 (3): 483-504.

Dillon M C (1983) Merlau-Ponty and the reversibility thesis. Man and World 16: 365-388. 
Dodge J, Ospina S M. andFoldy E G (2005) Integrating Rigor and Relevance in Public Administration Scholarship: The Contribution of Narrative Inquiry. Public Administration Review 65 (3): 286-300.

Dudley G (2000) New Theories and Policy Process Discontinuities. Symposium: Theories of the Policy Process. Journal of European Public Policy 7: 122-126.

Feldman M S (1989) Order without Design. Information Production and Policy Making. Stanford: Stanford University Press.

Feldman R (1999) Contextualism and Skepticism. Nous, Supplement: Philosophical Perspectives, “Epistemology”, 13: 91-114.

Feldman R (2001) Skeptical Problems, Contextualist Solutions. Philosophical Studies 103 (61): 6185.

Flyvbjerg B (2001). Making social science matter: Why social inquiry fails and how it can succeed again. Cambridge University Press.

Flyvbjerg B (2004), Phronetic Planning Research. Theoretical and Methodological Reflections. Planning Theory and Practice, 5 (3): 283-306.

Frei C (2001) Hans J. Morgenthau: An Intellectual Biography. Baton Rouge: Louisiana State University Press.

Gallop J (2006) Introduction: Envy. Women's Studies Quarterly 34 (3/4): 12-21.

Galtung J (2003) Cultural Peace: Some characteristics $\left(12^{\text {th }}\right.$ October 2003; available at https://www.transcend.org/files/article121.html (accessed March 2, 2017).

Habermas J (1994 [1968]), Knowledge and Human Interest. Oxford: Polity Press.

Habermas J (2008) Konstitutionalisierung des Völkerrechts und die Legitimationsprobleme einer verfassten Weltgesellschaft, In: Winfried Brugger et al. (eds) Rechtsphilosophie im 21. Jahrhundert. Frankfurt am Main: Suhrkamp, pp. 360-379, 375. 
Hamilton LC and Hamilton J D (1983) Dynamics of Terrorism. International Studies Quarterly 27 (1): 39-54.

Haraway D (1988) Situated Knowledges: The Science Question in Feminism and the Privilege of Partial Perspective. Feminist Studies 14:3, 575-599.

Hardin R (2003) Indeterminacy and Society, Princeton, NJ: Princeton University Press.

Hegel GWF (1975) Lectures on the philosophy of world history. Introduction, reason in history. (translated from the German edition of Johannes Hoffmeister from Hegel papers assembled by H. B. Nisbet). New York, NY: Cambridge University Press.

Henson R (1973) Correlativity and Reversibility. The Journal of Philosophy 70 (18): 648-649.

Hoeber-Rudolph S (2005) The Imperialism of Categories: Situating Knowledge in a Globalized World. Perspectives on Politics 3 (1): 5-14.

Holt E. B. et al. (1960) Introduction to the New Realism. In: Chisholm D (ed) Realism and the Background of Phenomenology, Illinois: Free Press of Glencoe, pp. 151-185.

Hom A (2018a) Silent Order: The temporal turn in critical International Relations. Millennium Journal of International Studies 46 (3): 303-330.

Hom A (2018b) Timing is Everything: Toward a Better Understanding of Time and International Politics. International Studies Quarterly 62 (1): 69-79.

Horkheimer M 1999 (1937) Traditional and critical theory. In: O'Connell (ed) Critical Theory: Selected Essays. New York: Continuum Press, pp. 188-243.

Hutchings K (2008) Time and World Politics: thinking the present, Manchester: Manchester University Press.

Introna L D (2007) Maintaining the reversibility of foldings: making the ethics (politics) of information technology visible. Ethics and Information technology 9: 11-25. 
Joppke C (2005) Are non-discriminatory immigration policies reversible? Evidence From the United States and Australia. Comparative Political Studies 38 (1): 3-25.

Jordan A et al. (2013) Policy Dismantling. Journal of European Public Policy 20 (5): 795-805.

Katzenstein P and Seybert LA (eds) (2018), Protean Power: Exploring the Uncertain and Unexpected in World Politics. Cambridge: Cambridge University Press.

Kessler O (2016) The Contingency of Constructivism: On Norms, the Social, and the Third. Millennium: Journal of International Studies 45 (1): 43-63.

Kozel SP (1995) Athikte's Voice: Listening to the Voice of the Dancer in Paul Valéry's "L'âme et la danse". Dance Research Journal 27 (1): 16-24.

Kratochwil F (1991) Rules, Norms, Decisions. On the Conditions of Practical and Legal Reasoning in International Relations and Domestic Affairs. Cambridge: Cambridge University Press.

Kratochwil F (2003) Reflections on Theory and Practice. EUI Working Paper SPS No. 2003/16, Badia Fiesolana, San Domenico (Florence, Italy).

Lasswell H and Kaplan A (1950) Power and Society. A Framework for Political Inquiry. New Haven: Yale University Press.

Lebgold J (1998), Is Anyone Listening? International Relations Theory and the Problem of Policy Relevance. Political Science Quarterly 113 (1): 43-62.

Levine D (2012) Recovering International Relations: The Promise of Sustainable Critique. Oxford: Oxford University Press.

Lindblom C (1968) The Policy-Making Process. New Jersey: Prentice Hall.

Mannheim K (1936) Ideology and Utopia. London: Routledge.

Mannheim K (1984) Die Methoden der Wissenssoziologie. In: Lenk K (ed) Ideologiekritik und Wissenssoziologie. Frankfurt: Campus, pp. 203-212.

Marcuse H (1941) Reason and Revolution. Hegel and the rise of social theory. London: Routledge and Keagan Paul Ltd. 
Marcuse H (1968) Negations: Essays in Critical Theory. London: The Penguin Press.

Marcuse H (2002 [1964]) One-Dimensional Man. London: Routledge.

McBeth M, Jones M D and Shanahan E (2014) The Narrative Policy Framework. In: Sabatier P A and Weible C (eds.) Theories of the Policy Process. Westview Press: Boulder: Colorado, pp. 225-266.

McCabe D (2010) Modus Vivendi Liberalism, Theory and Practice. Cambridge: Cambridge University Press.

McCourt DM (2012) What's At Stake in the Historical Turn? Theory, Practice, and Phronēsis in International Relations. Millennium: Journal of International Studies 41 (1): 23-42.

Molloy S (2009) Aristotle, Epicurus, and the political ethics of the lesser evil. Journal of International Political Theory 5 (1): 94.112.

Morgenthau HJ (1945) The evil of politics and the ethics of evil. Ethics 56 (1): 1-18.

Morgenthau HJ (1946) Scientific Man vs. Power Politics. Chicago: University of Chicago Press.

Morgenthau HJ (1954) Politics Among Nations. The Struggle for Power and Peace. New York: Knopf.

Morgenthau HJ (1962a) The Intellectual and Political Functions of a Theory of International Relations. In: Politics in the 20th Century, Vol. I, The Decline of Democratic Politics, Hans Morgenthau, Chicago, IL: University of Chicago Press, pp. 62-78.

Morgenthau HJ (1962b [1955]) Reflections on the State of Political Science. The Review of Politics 17 (4): 431-460.

Morgenthau HJ (2012) The Concept of the Political. Translated from the French by Vidal M, ed. by Behr H and Rösch F. Basingstoke/New York: Palgrave.

Mou B (2004) Reexamination of the Structure and Content of Confucius' Version of the Golden Rule. Philosophy East and West 54 (2): 218-248. 
Nason, S (2012) Contingency, Necessity, and Causation in Kierkegaard's theory of change. British Journal for the History of Philosophy 20 (1): 141-162.

Neisser U (1973) Reversibility of Psychiatric Diagnoses. Science, New Series 180 (4091): 1116.

Nietzsche F (2003) The Gay Science: With a Prelude in German Rhymes and an Appendix of Songs. Cambridge: Cambridge University Press.

Nussbaum MC (1990) The discernment of perception: An Aristotelian conception of private and public rationality. In: Love's knowledge: Essays on philosophy and literature. Oxford: Oxford University Press, 54-105.

Palumbi S R, McLeod K L, and Gruenbaum D (2008) Ecosystems in Action: Lessons from Marine Ecology about Recovery, Resistance, and Reversibility. BioScience 58 (1): 33-42.

Parsons W (2000) When Dogs Don't Bark: New Theories and Policy Process. Symposium Theories of the Policy Process. Journal of European Public Policy 7: 126-130.

Patillo C (1998) Investment, Uncertainty, and Irreversibility in Ghana. Staff Papers (International Monetary Fund) 45 (3): 522-553.

Pridham G (2007) Status quo bias or institutionalisation for reversibility? The EU's political conditionality, post-accession tendencies and democratic consolidation in Slovakia. Europe-Asia Studies 60 (3): 423-454.

Ramsey JB and Rothman P (1996) Time Irreversibility and Business Cycle Asymmetry. Journal of Money, Credit and Banking 28 (1): 1-21.

Rengger N. and Thirkell-White B (eds.) (2012) Critical International Relations Theory after 25 years Cambridge: Cambridge University Press.

Rooney E (2017) Symptomatic Reading Is a Problem of Form. In: Elizabeth S Anker and Rita Felski (eds) Critique and Postcritique. Durham/NC: Duke University Press.

Rorty R (1989) Contingency, irony, and solidarity. Cambridge: Cambridge University Press. Rose R (2005) Learning from Comparative Public Policy. Abingdon/New York: Routledge. 
Sabatier P A (1991) Toward Better Theories of the Policy Process. Political Science and Politics 24 (2): 147-156.

Sabatier P A (1999) The Need for Better Theories. In Sabatier P A (ed) Theories of the Policy Process. Boulder/Col.: Westview Press, pp. 3-18.

Sarukkai S (2002) Inside/Outside: Merleau-Ponty/Yoga. Philosophy East and West 52 (4): 459-478.

Saurugger S (2013) Constructivism and public policy approaches in the EU: from ideas to power games. Journal of European Public Policy 20 (6): 888-906.

Schütz, A (1962) The Problem of Social Reality, Collected Papers I. The Hague: Martinus Nijhoff. Schmitter P (2002/2003) Neo-neo-functionalism. European University Institute (together with Arne Niemann). In: Wiener A and Diez Th (eds) European Integration Theory. Oxford: Oxford University Press, pp. 45-66.

Schneider A, Ingram H and Deleon P (2014) Democratic Policy Design: Social Construction of Target Populations. In: Sabatier P A and Weible C (eds) Theories of the Policy Process. Westview Press: Boulder: Colorado, pp. 105-149.

Shanahan E, Jones M D., McBeth M K., and Lane R (2013) An Angel on the Wind: How Heroic Policy Narratives Shape Policy Realities. The Policy Studies Journal 41 (3): 453-483.

Sharkansky I (2002) Politics and Policymaking: In Search of Simplicity. Boulder/Col.: Westview Press.

Simmel G (1977) The Problems of the Philosophy of History. An Epistemological Essay. Translated and edited, with an Introduction by Guy Oakes, New York: The Free Press.

Smith S (2003) International Relations and international relations: The Links Between Theory and Practice in World Politics. Journal of International Relations and Development 6 (3): 233-239. Stawarska B (2002) Reversibility and intersubjectivity in Merleau-Ponty's ontology. Journal of the British Society for Phenomenology 33 (2): 155-166. 
Steele BJ (2007) Eavesdropping on honored ghosts: from classical to reflexive realism. Journal of International Relations and Development 10 (3): 272-300.

Steinberg P E (2014) Steering between Scylla and Charybdis: The Northwest Passage as Territorial Sea. Ocean Development \& International Law 45 (1): 84-106.

Taylor C. (1989) Sources of the Self. The making of modern identity. Cambridge: Harvard University Press.

Taylor C (1971) Interpretation and the Sciences of Man. The Review of Metaphysics 25 (1): 3-51.

Tymieniecka A T (2009) The Fullness of the Logos in the Key of Life: Book I The Case of God in the New Enlightenment. Yearbook of Phenomenological Research, Volume C, Springer - Science and Business Media.

Voegelin E (1978) Anamnesis. Edited and translated Gerhart Niemeyer. Notre Dame: University of Notre.

Voegelin E (1999 [1938]) Die politischen Religionen [The political religions]. The Collected Works of Eric Voegelin. Volume 5. Columbia and London: University of Missouri Press.

Voegelin E (2002) What is political reality? In: Anamnesis: On the Theory of History and Politics. The Collected Works of Eric Voegelin. Volume 6. Columbia and London: University of Missouri Press.

Voegelin E (2006) Autobiographical Reflections. The Collected Works of Eric Voegelin. Volume 34. Columbia and London: University of Missouri Press.

Walt, SM (2005) The Relationship Between Theory and Policy in International Relations. Annual Review of Political Science 8: 23-48.

Weible C (2014) Introducing the Scope and Focus of Policy Process Research and Theory. In: Sabatier P A and Weible C (eds) Theories of the Policy Process. Westview Press: Boulder: Colorado 2014, pp. 3-23. 
Williams M C (2004) Why Ideas Matter: Hans Morgenthau, Classical Realism, and the Moral Construction of Power Politics. International Organization 58 (4): 633 - 665.

Wilson J Q (1989) Bureaucracy: What Government Agencies Do and Why They Do It. New York: Basic Books.

Yagi S (1982) Japanese Christian Theology in Encounter with Buddhism. Buddhist-Christian Studies 2: $131-135$.

Yalvaç F (2015) Critical Theory: International Relations' Engagement With the Frankfurt School and Marxism. International Studies, Print Publication Date: Dec 2015, DOI: 10.1093/acrefore/9780190846626.013.109

Young I M (1994) Comments on Seyla Benhabib, Situating the Self. New German Critique 62: 165172.

Zahariadis, N (2014) Building better theoretical frameworks of the European Union's policy process. Journal of European Public Policy 20 (6), 807-816.

Zalewski, M (1996), All these theories yet the bodies keep piling up': theories, theorists, theorising. In: Smith S, Booth K, and Zalewksi M (eds) International theory: positivism and beyond. Cambridge: Cambridge University Press, pp. 340-353. 